\section{Have bombs spread?}

Crypto-nuclear powers may be as dangerous as the genuine article.

LAST week's dispute between Hungary and Romania about the disposal of 12.5 tonnes of Norwegian heavy water (page 384) is more than merely another sign of the growing readiness of Eastern European countries to be seen squabbling in public; it is also a reminder that the Nuclear Non-Proliferation Treaty (NPT) needs continuing attention, certainly more attention than it has been getting in the past year's excitement about other negotiations in arms control, of which the INF treaty is the tangible product so far. Much the same conclusion can be derived from the conviction last month of Mr Moredechai Vununu, an Israeli technician, of treason after a trial held in camera before a military court. The case against Vununu stemmed from his disclosure to a London newspaper (the Sunday Times) last year of information about Israeli operations at the Dimona reactor site in the Negev. Vununu's allegations, as eventually published, were that Dimona has a secret plant in which plutonium can be (and is) separated from reactor fuel. None of this circumstantial evidence proves that Israel is already a nuclear power, but it does suggest that familiarity - and perhaps even the welcome relaxation of tension between superpowers - is breeding sloppiness in people's regard for the danger that nuclear weapons will spread.

The case of Mr Vununu is like a problem in logic-chopping for undergraduates. There are two premises: either he was lying when he talked to the newspapers, or he was telling the truth. To lie so as to suggest that a government is making nuclear weapons when it is not may plainly be categorized as "slandering the state", but that misdemeanour does not feature in Israel's criminal code, and hardly ranks as treason, so that the conviction must be unjust. If, on the other hand, $\mathrm{Mr}$ Vununu was telling the truth, both the conviction and the secrecy of the trial are explicable, but then it is difficult to understand why Israel chose to hold a trial whose outcome could only reinforce the suspicion that Israel is, secretly, already a nuclear power.

There are, of course, other possibilities. Mr Vununu may have broken obligations of confidentiality towards the Israeli public service in much the way that Mr Peter Wright, the retired British intelligence officer, has offended the British government, but then one would have expected an explanation to that effect to have been forthcoming. Alternatively (requiring cynicism of an unusual degree), Mr Vununu may be neither a liar nor an honest man but a participant in a charade whose objective, after the leaking of intriguing but misleading information, a secret trial and a conviction, was to remind states in the Middle East of Israel's status as a crypto-nuclear power.

Whatever the truth, Israel's nuclear status remains much what it has been for a quarter of a century. The original Dinoma reactor, a water-cooled reactor of the kind commonly called a "materials-testing reactor" in the late $1950 \mathrm{~s}$, and built with French assistance, could have produced enough plutonium to make one bomb a year even if its power rating had not been increased, as Mr Vununu suggested. Israel has never carried out a nuclear test, it is true, but neither has it compellingly denied that it has nuclear weapons, signed the NPT or opened Dimona to international inspection. And Israel is not alone. During the past few years, and especially since the onset of trouble in Afghanistan a decade ago, Pakistan has been talking and behaving in much the same way. So much of the technology of nuclear energy is now so familiar that a government wishing to suggest to its neighbours that it has nuclear weapons up its sleeve can do so without incurring the full expense of actually making bombs, but in the process necessarily creates the impression that nuclear weapons have indeed spread.

The governments whose interest is to prevent the spread of nuclear weapons appear not to appreciate the dangers of the growing conviction that proliferation is not merely unavoidable but already under way. If it were otherwise, they would be more vigilant in enforcing the rules of the agreement between nuclear suppliers that bits and pieces of nuclear plants will not be sold to anybody who wishes to buy them. (It is not a joke that 15 tons of Norwegian heavy water exported in 1983 cannot now be accounted for, or that there is confusion about the earlier shipment to Romania.) More to the point, the two major powers should be more diligent in exerting the influence of which they are fond of boasting in the sense of persuading their dependent allies to toe the line of non-proliferation. There are also issues that should be dealt with within the framework of the NPT, to which almost only the crypto-nuclear powers do not belong. Why not plan to persuade France and China, both declared nuclear powers, to join the treaty by the time of the next review conference in 1990, and to find some kind of accomodation with the crypto-nuclear powers (India is the most willing to talk) by that date? It might be necessary to pay a price, say a comprehensive test-ban, but that would be no bad thing.

\section{Burying von Humboldt?}

\section{Extra money is only a partial remedy for West}

\section{Germany's universities.}

IN a misanthropic world, it is inevitable that people should take comfort in others' misfortunes. Thus academics almost everywhere will read with guilty pleasure the account on page 385 of the problems of West Germany's universities and of the remedies proposed for them by the Wissenschaftsrat. For even if many of the misfortunes confronting West German academics are in some sense general, some of them are peculiar to West Germany and also self-inflicted. But there can be no joy in a situation where it seems that, yet again, the weight of events conspires against the the marriage of research with teaching in higher education - Prussian von Humboldt's eighteenth-century legacy to the rest of Europe.

Not that the causes of the drift of researchers towards research institutes are that mysterious. The mounting cost of research equipment argues for the provision of central facilities. In West Germany and many other European systems, great national enterprises (nuclear energy, aeronautics, now scientific medicine) have created large groups of researchers with no choice but to adapt to changing circumstances by diversifying their activities, competing with universities not just for funds but people. West Germany's distinctive network of Max-Planck institutes may not be as serious a threat to the strength of university research as they may seem, given that they often crystallize around university groups or are otherwise sited intelligently. Yet the institutes assist researchers who believe teaching to be temporarily an encumbrance to escape from it for good. As competitive pressures further strengthen, the temptation to escape can only become stronger.

The Wissenschaftsrat's remedies are sensible in themselves, but are unlikely to be sufficient. More money for university research (presumably through the Deutsche Forschungsgemeinschaft or DFG) would no doubt help a little, but the federal government is already panicky about the impending decrease of taxation rates, and is unlikely to share that view. The much more serious difficulty is that the reputation of the German university system, false though it is, suggests a general air of chaos. Too many universities are too big. Too many students stay too long. Legal battles between universities and their students and/or teachers may have declined in number during the past decade, but folk-memories persist. But what most West German universities have on their side is the knowledge that they are not simply part of a national system, but also the creatures of their regional governments. After the excesses of the great expansion, some Land government may yet see the virtue of running a tight ship in higher education. 